\title{
IAMJ
}

INTERNATIONAL

AYURVEDIC

MEDICAL JOURNAL

\section{CRITICAL REVIEW ON GARBHAJANYA VIKRITI (BIRTH DEFECTS) DESCRIBED IN AYURVEDA AND ITS MODERN ASPECT}

\author{
$\underline{\text { Anubha Srivastava }}^{1}, \underline{\text { Anjana Saxena }}^{2}, \underline{\text { Vijay Kumar Srivastava }}^{3}, \underline{\text { Ashutosh Kumar Yadav }}^{4}$ \\ ${ }^{1}$ Assistant Professor and PhD scholar, Department of Rachana Sharir, Government Ayurveda PG College, SSU, \\ Varanasi - INDIA-221002 \\ ${ }^{2}$ Assistant Professor, Department of Prasuti tantra and Streeroga, Government Ayurveda PG College, SSU, \\ Varanasi- INDIA-221002 \\ ${ }^{3}$ Assistant Professor, Department of Panchakarma, Faculty of Ayurveda, IMS, BHU, \\ Varanasi-INDIA-221005 \\ ${ }^{4}$ Associate Professor, Department of Rachana Sharir, Government Ayurveda PG College, SSU, \\ Varanasi- INDIA-221002
}

Corresponding Author: hianubha27@gmail.com

\section{https://doi.org/10.46607/iamj0909062021}

(Published Online: June 2021)

Open Access

(C) International Ayurvedic Medical Journal, India 2021

Article Received:10/05/2021 - Peer Reviewed:03/06/2021 - Accepted for Publication:04/06/2021

Check for updates

\begin{abstract}
Ayurveda is the most ancient medical science and its fundamentals cover every aspect of human life. Acharya Sushruta has classified the diseases into seven types on the basis of its origin; among them first two are explained for birth defects. Genetic disorders (Adibala pravritta) and Congenital anomaly (Janmabala pravritta) are the two main categories of birth defects (Garbhajanya vikriti) encountered during the early infancy. The genetic disorders are either maternal or paternal and largely responsible for carrying genetic defects in progeny, whereas congenital birth defects are mainly due to faulty diet and lifestyle of mother and due to suppression of mental and physical desire of the pregnant lady. Ayurveda enlisted various desires of pregnant woman and their impact on the health and physical status of the progeny. Similarly, there are so many rituals and regimens are described for pregnant lady to prevent birth defects and to make woman ready for normal delivery. In brief, it can be said that if a preg-
\end{abstract}


nant lady wishes for a healthy baby (Supraja), She should follow the Nine-month regimen (GarbhiniParicharya) mentioned for them in Ayurveda, so the chances of congenital anomaly will be minimal.

Keywords: Congenital anomaly, Birth defect, Garbhajanya vikriti, Supraja, Garbhini paricharya

\section{INTRODUCTION}

Garbhajanya Vikriti or Birth defect is a big medical challenge for medical practitioners all over the world. On evaluation of literatures, it is evident that the Garbhajanya vikriti which are described in Ayurveda Samhita thousands of years before are exactly in order as illustrated in Teratology or birth defect mentioned in modern texts. Acharya Sushrut said that diseases are of seven types depending on their nature of origin; among them first two are responsible for birth defects $^{1}$. Adibala pravritta (Genetic disorders) and Janmabala pravritta (Congenital anomaly) are the two main categories of birth defects (Garbhajanya vikriti) along with vitiation of Ritu (Age and mating time) and Kshetra (Uterus) ${ }^{2}$. The genetic disorders are either maternal or paternal and largely responsible for carrying genetic defects in progeny, whereas congenital birth defects are mainly due to faulty diet and lifestyle of mother and due to suppression of mental and physical desire of the pregnant lady $^{3}$. Congenital anomaly or malformation or birth defect is a physical or mental abnormality present in a baby at birth, it can involve different parts of the body for example cleft lip, cleft palate, polydactly, meningo-mylocoel, hydrocephalous, Down's syndrome, ADHD etc ${ }^{4}$. Acharya Sushruta versed that, if a pregnant woman wishes for healthy baby or Supraja ${ }^{5}$ should follow the regime properly mentioned for them, so the chances of congenital anomaly will be minimal.

\section{Ayurveda review-}

Ayurveda is having the pride of oldest medical science and its thought and concepts are gifts for modern medical world. In classical Ayurvedic texts Garbha (Embryo-Foetus), Garbhotpatti (Conception), Garbhavkranti (embryonic development), Garbhjanya vikriti (Birth defects) and Garbhini Masanumasik krama (monthly regime during pregnancy) are very clearly described, and if a pregnant lady follow these advises will not suffer by any birth defects in progeny.
In another reference during the classification of diseases (Vyadhi) Acharya Sushruta has classified the diseases in to seven types and among them two are related to early infancy or childhood disorders.

\subsection{Garbha (Foetus)-}

According to Acharya Sushruta the coalition of Shukra (Sperm) and Sonita (Ova) implanted in the Garbhashaya (Uterus) along with Aatma (Soul), Prakriti (Basic essence) and Vikar (Traits) is known as Garbha (Embryo-Foetus) ${ }^{7}$. Acharya Vagbhata said that the body formed by the fusion of Shukra and Aartava gets divided by Vata dosha leading to the creation of one or more Garbha and if abnormal there will be formation of defective embryo ${ }^{8}$.

\subsection{Garbhotpatti (Pregnancy)-}

Acharya Sushruta said that for Garbhotpatti (Pregnancy) four things are essential; they are Ritu (Age and mating time), Kshetra (healthy uterus), Ambu (uninterrupted nourishing fluid) and Bija (sperm and ova). Any abnormality in any of these may leads to malformation in to the foetus ${ }^{2}$.

\subsection{Garbhavkranti (Descent of Embryo)-}

The process of descent of various components in embryo is Garbhavkranti ${ }^{9}$ and its development is Garbha Vriddhi. In modern context we can understand it as Embryological development. The various Garbha vriddhikar Bhavas are 6 in number viz Matrija (Maternal), Pitraja (Paternal), Atmaja (Soul), Satmyaj (Great essence), Rasaj (Nourishing) and Satvaj (Psychic factors $)^{10}$.

\subsection{Garbha Masanumasik Vriddhikrama (Embry- onic development)-}

The Garbha or foetus has followed a typical development process to attain the shape of a complete baby, and Acharya Charak describes it in a sequence of month wise maturity ${ }^{11}$.

- It is formed as 'Kalala' by the union of sperm and ova; it comprises all the organs in minute form. It 
appears like jelly on first day and within 7 days like frothy, within fort night like bolus and at the end of month it solidifies.

- In second month, it is influenced by 'Tridosha' and become a solid mass of Panchmahabhuta with Atma. If it is of Pinda shape (ball like) than offspring would be a male child, if it is of Peshi shape (elongated) than future of baby is female child and if it like Arbuda (deformed) than it will be a hermaphrodite child.

- In third month, the foetus grows and develops into five buds (Panch pindika) i.e. two arms, two legs and one head-trunk. All the organs of the body and their subdivisions of organs are in the minute form.

- In the fourth month all the organs (AngaPratyanga) and their subdivisions become visible. 'Chetan dhatu' also get manifested in this month, and the foetal heart become obvious, so the mother possesses two hearts at this stage and known as 'Dauhridini'. Non fulfilment of desires of the pregnant lady may leads to the birth of a child with congenital birth anomalies.

- In the fifth month the mind and wisdom become more noticeable and developed.

- In the sixth month the wisdom is perceived.

- In the seventh month all Anga-Pratyanga are become more obvious.

- This is a very vulnerable time because the Ojus becomes unsteady in this period; and it moves between the mother and foetus. So, there are a lot of chances to give a still birth due to unsteadiness of the Ojus.

- Usually in the ninth month delivery takes place with a full developed progeny. Sometimes it may take place in the $10^{\text {th }}, 11^{\text {th }}$ or $12^{\text {th }}$ month. Otherwise it should be regarded as abnormal (Vikari).

\subsection{Garbhajanya vikriti (Congenital anomaly)-} According to Acharya Sushrut the reason for Garbhajanyavikriti are Nastikata (atheist), and Ashubha karma (sinful acts) of parents and Purvajanmakrita kar$m a$ (action done in previous life) of parent and foetus, it will lead to Vata prakopa during pregnancy and causes birth defects. Foetus resembling to Sarpa (snake), Vrashchika (scorpion), Kusmanda (pumpkin) and having such abnormal shape (Vikriti) due to the Paap karma (sinful act) of mother. Further Vata prkopa and Dauhridavmanana (Non fulfilment of desires of woman during pregnancy) are the causing factors for giving birth of Kubja (Humped back), Kuni (deformed arm), Pangu (lame), Muka (Dumb) andMinmin (nasal voice) child ${ }^{12}$.

According to Acharya Charak the woman give birth to an abnormal offspring due to the defects in seeds (Sperm and Ovum), actions associated with the soul (Karma), physical condition of the uterus (Garbhashaya), age of lady and mating time (Kaala), dosha predominance of woman and daily foodregimen of the mother; doshas get variously vitiated and this results in the impairment of the shape, colour, sensory and motor organs of the offspring. As a wood piece (Kashtha) standing in the current of a river gets distorted by the forceful downward movement of water and stone during rainy season, so the foetus in the uterus of the mother gets deformed with the vitiated doshas ${ }^{31}$.

Development of Anga-Pratyanga (main parts and appendages) of the Garbha or foetus is an autonomic process and took place naturally (Svabhava) and Guna-Avaguna of this development is solely depends on the Dharma (Righteous act) and Adharma (Sinful act) karma of parents and Foetus of previous life (Purva janmakrita karma).

\subsection{Types of Garbhavikriti-}

Garbha is a product of Shukra (sperm), Sonita (ovum), Jiva (soul), Prakriti (basic trait) and Vikar (panchamahabhuta) during proper Ritu (age and time of mating), at healthy Kshetra (Uterus) and with the nourishment of Ambu (Nutritive supply) ${ }^{2}$. So, any abnormality in the above prerequisite can lead to the malformation of the foetus and later in the progeny. The Acharyas described this issue with various angles.

\subsubsection{Adibalapravritta vikriti (Genetic disorders)-}

Diseases those are produced due to the abnormalities in Shukra (Sperm) and/ or in Shonita (Ovum) such as Kushtha (leprosy), Arsha (piles) etc are known as Adibalapravrita vyadhi ${ }^{1}$. They are of two types. 


\subsubsection{Matrija (Maternal)-}

The maternal reproductive part is Stribija or female germ cell or ovum; the other terms in Ayurvedic literature are Artav, Raja, Asraka etc. The purpose of Bija is for the creation of new life after the union of pumbi$j a$ and stribija. Pumbija contribute the paternal inheritance while the stribija contribute the maternal inheritance to the progeny ${ }^{13}{ }^{14}$. When the bijabhaga in the ovum of mother which is responsible for the production of uterus is excessively vitiated, then she gives birth to a Bandhya, infertile child. When the bijabhagavayav in the ovum of the mother which is responsible for the production of the uterus is excessively vitiated, then she gives birth to a Putipraja child. When the bijabhgavayav which is responsible for the production of uterus and also bijabhaga which are responsible for the production of organ that characterized a female in the ovum are excessively vitiated then she gives to a child who is not a complete female but only having the feminine characteristic in abundance such type of child is known as Varta and that condition is also included in twenty types of Strivyapad (Feminine disorders $)^{15}$.

\subsubsection{Pitraja (Paternal)-}

The Paternal reproductive part is Pumbija, the synonyms are Retas and Shukra. According to Charak when the part of bija which is responsible for the formation of genital organ (penis \& scrotum) in the foetus is excessively vitiated, then this give birth to a Bandhya, infertile child. When the bijabhgavayav (only a fraction of the part of bija) which is responsible for the production of sperm is excessively vitiated then this gives birth to a Putipraja (child dies before delivery), and when the bijabhagavayav which is responsible for production of sperm and also bijabhaga that characterized a male which is excessively vitiated, then this gives birth to a child who is not completely male but only have masculine characteristic in abundance such type of child is known as Tranaputrika that condition is called Purushavyapad (Masculine disorders) ${ }^{16}$.

\subsubsection{Janmabalapravritta vikriti (Birth defects)-}

The diseases those are produced by improper diet and conduct (Ahar-Vihar) of the pregnant woman and suppression of desires during pregnancy will leads to abnormalities in the child such as (Pangu) lameness, (Andha) blindness, (Badhir) deafness, (Muka) muteness, (Min min) nasal speech, (Vaman) dwarfness, (Kubja) hump, (Kuni) Maimed etc. ${ }^{12}$ all by birth are known as Janmabalapravrita Vyadhi, again these are of two types

\subsubsection{Rasakrita (Nourishing factors)-}

Rasakrita disorders are produced by faulty diet and lifestyle of the lady during anti natal period. Acharya Charak has clearly explained the nine month diet and regimen for the pregnant lady (Masanumasik Garbhini paricharya); if it is properly adopted by pregnant woman it will encourage the growth of foetus without causing malformation and if not leads to various congenital anomaly ${ }^{12}$.

\subsubsection{Dauhridavamanana (Psychological factors of Pregnant woman)-}

Acharya Sushruta has said in the description of Dauhrida that whichever thing is desired by pregnant woman should be given to her. Only after getting her desires fulfilled, she gives birth to a son who will be brave and long lived. By not fulfilling these desires the woman will give birth to a child who is either a hunch back, of distorted arms, foolish, lame, inactive, dwarf, of distorted eyes or absence of eyes and blind $^{12}$.

\subsubsection{Ritujanit (Age and mating time)-}

According to Acharya Charak and Sushruta the lady should not be very young or old for pregnancy. If a woman below 16 is impregnated by a man below 25 either she will not conceive if conceive she will have intra uterine death of foetus; if the child is born it would not live long or will have weak and deformed organs and have ill health ${ }^{17}$.According to Arundatt if the mating is taken place on Ekadashi (11 $1^{\text {th }}$ day of Shukla and Krishna paksha) and Trayodashi (13 ${ }^{\text {th }}$ day of Shukla and Krishna paksha) there is a birth of $\mathrm{Na}$ punshak (Eunuch) and progeny takes birth with less and weak body parts ${ }^{18}$.

\subsubsection{Kshetra janit (Uterus) -}

The normal structure and position of uterus (Garbhashaya) is essential for normal pregnancy and uninterrupted development of foetus. The normal 
uterus is defined as like mouth of Rohit fish, and it is situated in third avarta of Shankhanabhikriti Yo$\mathrm{ni}^{19}$.Upshuska (Dry foetus), Nagodara (delayed pregnancy) are the usual complications when the uterus is unhealthy.

\section{Modern review-}

After the extensive advancement in the studies of birth related disorders, a new branch is developed in modern medical science 'Teratology'; to study the birth defects and congenital anomalies in foetus.

\subsection{Teratology-}

It is the scientific study of congenital abnormalities of foetus during the period of embryonic development. Teratology comes from the Greek word "Teras" meaning monster or marvel, the discipline, which deals anomalies. In contemporary usage, the term teratology generally refers to disfiguring birth defects or malformations. Currently, its most instrumental meaning is that of the medical study of teratogenesis, congenital malformations or grossly deformed individuals, with greater understanding of the origins of basic science, including developmental biology, embryology, and genetics. There are a few definitions closely related to explain the term teratology like congenital physical anomaly, congenital malformations, birth defect, Genetic disorder and congenital metabolic diseases $^{20}$. Teratology as a medical term was popularized by Dr. David W. Smith of the University of Washington.

Broadly a congenital physical anomaly is an abnormality of the structure of a body part not perceived as a problem; like curvature of the 5th finger, a third nipple, tiny indentations of the skin near the ears (Pre auricular pit), Dimples over the lower spine etc. Whereas a congenital malformation is a physical anomaly that is deleterious and hampering the normal function. A congenital metabolic disease is also referred to as an inborn error of metabolism. Most of these are single gene defects, usually heritable, many affect the structure of body parts, but some simply affect the function ${ }^{20}$.

\subsection{Birth defects-}

Term Birth defect is a widely used term for a congenital malformation i.e. a congenital, physical anomaly which is recognizable at birth, and which is significant enough to be considered a problem ${ }^{23}$. Most birth defects are believed to be caused by behaviours, though many birth defects have unknown cause. Genetic disorder or diseases are all congenital, though they may not be expressed or recognized until later in life. Genetic diseases may be divided into Single-gene defects, Multiple-gene disorders and Chromosomal defects $^{24}$. A congenital metabolic disease is also referred to as an in born error of metabolism. Most of these are single gene defects, usually heritable ${ }^{25}$.

\subsection{Teratogenesis-}

Birth defects are known to occur in 3-5\% of all newborns. Although significant progress has been made in identifying etiologic causes of some birth defects, approximately $65 \%$ have no known or identifiable cause. It was previously believed that the mammalianembryo developed in the impervious uterus of the mother, protected from all extrinsic factors. However, after the thalidomide disaster of the 1960s, it became apparent and more accepted that the developing embryo could be highly vulnerable to certain environmental agents that have negligible or non-toxic effects to adult individuals. They are the leading cause of infant mortality in the United States, accounting for more than $20 \%$ of all infant deaths. Seven to ten percent of all children will require extensive medical care to diagnose or treat a birth defect. Exposure to teratogens can result in a wide range of structural abnormalities such as cleft lip, cleft palate, dysmelia, anencephaly, Ventricular septal defects. In most cases, specific agents produce a specific teratogenic response ${ }^{20}$.

\subsection{Wilson's Six Principles-}

According to Wilsons Principle the susceptibility to teratogenesis depends on the genotype of the conception and the manner in which this interacts with adverse environmental factors. Susceptibility to teratogenesis varies with the developmental stage at the time of exposure to an adverse influence. There are critical periods of susceptibility to agents and organ systems affected by these agents. Teratogenic agents act in specific ways on developing cells and tissues to initiate sequences of birth defects. The adverse influences to developing tissues depend on the nature of 
the influence. Several factors affect the ability of abnormal events of a teratogen to contact a developing conceptus, such as the nature of the agent itself, route and degree of maternal exposure, rate of placental transfer and systemic absorption, and composition of the maternal and embryonic/fetal genotypes ${ }^{21}$.

\subsection{Teratogenic agents-}

There are various types of Teratogenic agents classified in modern texts, which are harmful for the foetus. They are Ionizing radiation like atomic weapons, radioiodine and radiation therapy. Another group is infections of pregnant lady with cytomegalo virus, herpes virus, parvovirus B-19, rubella virus (German measles), syphilis, toxoplasmosis etc. The Metabolic imbalance like alcoholism, endemic cretinism, diabetes, folic acid deficiency, and hyperthermia are included. Drugs and environmental chemicals are hazardous like 13-cis-retinoic acid, isotretinoin, nitrazepam, androgenic hormones, busulfan, enalapril, organic mercury, penicillamine, tetracyclines, thalidomide, trimethadione, uranium, methoxyethyl ethers and valproic $\operatorname{acid}^{22}$.

\section{DISCUSSION}

Ayurveda has two basic objectives; the first is to keep the healthy person healthy and second is to treat ifhe becomes diseased. The first purpose included various modalities like Svasthvritta (Hygiene), Sadavritta (Mental conducts), Dincharya (Daily routine), Ritucharya (Seasonal regime), Rasayan (Rejuvenation), Nidanparivarjan (Do's and Don'ts) etc as preventive aspect. Among these descriptions to save the progeny from birth defects (Garbhajanya vikriti) a very important daily regimen for pregnant lady is elaborated known as Garbhini masanumasik paricharya. Acharya Sushrut said that Adibalapravritta (Genetic disorders) and Janmabalapravritta (Congenital malformation) are the two main categories of birth defects (Garbhajanya vikriti) along with the defects caused by vitiation of Ritu (Age and mating time) and Kshetra (Uterus).

According to Acharya Charak and Sushruta the lady should not be very young or old for pregnancy. If a woman below 16 is impregnated by a man below 25 either she will not conceive if conceive she will have intra uterine death of foetus; if the child is born it would not live long or will have weak and deformed organs and have ill health. Expert says the best time to get pregnant is between 20 to 30 years of age ${ }^{32}$. The chances of getting pregnant is decreases with age; like after three months of trying the probability of conceiving is 18 percent at age 25,16 percent at age 30,12 percent at age 35 and just 7 percent at the age of 40 years. Away from many pre and post-natal complications chromosomal abnormalities like Down's syndrome become more obvious at aged pregnancy. An article has been shown that there is association between extreme maternal age and congenital malformations is $U$ shaped with higher proportion of malformed children among women aged less than 20 years or more than 39 years ${ }^{27}$. This is especially true for chromosomal abnormalities among the women of advance ages and disruptive malformation among teenage mothers, IrisaZile et al. Medicina also conclude that maternal age associated with congenital anomalies among newborn ${ }^{28}$. Acharya Susruta also kept focus on the mating time he has suggested that a man should not performed coitus with her wife in first 3 days of menstruation because conception in these days may result pseudo pregnancy, baby with birth defects and may be still birth or dead baby ${ }^{29}$.

Uterus (Kshetra) is working as the abode for developing foetus, it should be disease free and healthy otherwise dry and emaciated baby can be delivered or a delayed pregnancy will result due to interrupted blood and nutritional supply to the foetus. The normal structure and position of uterus (Garbhashaya) is essential for normal pregnancy and uninterrupted development of foetus. The normal uterus is defined as like a mouth of Rohit fish, and it is situated in third circle (avarta) of Shankhanabhikriti Yoni (Vagina). The medical reviewed by Alana Biggers. M, d MPH-Written by Julie Marks updated on July 26, 2017 that women with a bicornuate uterus (Heart- shaped) may have risk of repeated miscarriage, and the babies born to the mothers with bicornuate uterus have a greater chance of developing birth defect compared to those born to women without the condition. 
The genetic disorders are either maternal or paternal and largely responsible for carrying genetic defects in progeny, for example Acharya Charak has described Varta, Bandhya, Diwereta, Putipraja, Pawanendriya in reference to Beejadushti and on observing their features they are similar to Genetic disorders like Down's Syndrome' (Trisomy-21), Turner's Syndrome (45 X), (45 X0), Klinefelter Syndrome (47 XXY) described in modern text. Similarly, many skin and hair disorders, varicose veins and metabolic disorders are having hereditary influence. To suppress these inherited disorders Acharyas suggest for marriages in different Gotras (clan). In Hindu system the Gotra is decided by the eight Rishis on their lineage basis: Angirasa, Atri, Gautam, Kashyapa, Bhrigu, Vashishtha, Vishvamitra and Bhardwaja. It is evident from the researches that if there is a recessive dangerous gene in one person is marrying to a person of opposite Gotra will remain unexpressed, but as soon as this person marry to a same Gotra person this lineage will leads to the production of defective gene and express the disease. So, it is said that the marriages between cousins will increase the risk of causing genetic disorders $^{33}$. There is a four-clan rule to follow these exogamy marriages; that a man must not marry a woman from his father's gotra, his mother's gotra, his father's mother's gotra and his mother's gotra ${ }^{34}$.

Congenital birth defects are encountered mainly due to faulty diet and life style of mother and due to suppression of mental and physical desire of the pregnant lady these are lameness (Pangu), blindness (Andha), deafness (Badhir), muteness (Muka), nasal speech (Min min), dwarfness (Vaaman), hump (Kubja), Maimed (Kuni) etc. all by birth. These are of two types: Rasakrit and Dauhridakrita. Rasakrita disorders are produced by faulty diet \& lifestyle (papkritkarm) of the lady during anti natal period and that leads to the development of monster baby because the shape of the foetus resembles to Sarpa (Snake), Vrischik (scorpion), Kushmanda (pumpkin) etc. To address this issue Acharya Charak has given the example of a water current making distortion in the shape of a wooden block, so the foetus in the uterus of the mother gets afflicted with the vitiated doshas and changes in its shape ${ }^{31}$. We can see that during the embryonic development phase the germinating cells are surrounded by water filled cavities and in this watery medium the developing cells slides over each other to give them a shape. Sometimes due to faulty physical position of the pregnant lady or due to consumption of excessive Vata alleviating diet and lifestyle this water body gets turbulence. This turbulence will lead to the uneven division of germinating cells and formation of monster baby or defective formation of body parts and appendages. Teratologists exposed pregnant animals to environmental agents and observed the foetuses for gross visceral and skeletal abnormalities like Cleft lip, Cleft palate, Polydactly etc. While this is still part of the Teratological evaluation procedures today, the field of Teratology is moving to a more molecular level, seeking the mechanism(s) of action by which these agents act. These studies provide information about possible risks of medications or other exposures in human pregnancies. Understanding how a teratogen causes its effect is not only important in preventing congenital abnormalities but also has the potential for developing new therapeutic drugs safe for use in pregnant women. It is estimated that $10 \%$ of all birth defects are caused by a prenatal exposure of teratogen. These exposures include, but are not limited to, medication or drug exposures, maternal infections and diseases, environmental exposures, occupational exposures. Teratogen caused birth defects are potentially preventable; studies have shown that nearly $50 \%$ of pregnant women have been exposed to at least one medication during gestation ${ }^{26}$.

Dauhridakrit disorders are mainly Vata predominance disorders and produced due to the non-fulfilment of desires of the pregnant women like birth of Kubja (Hump backed), Kuni (crooked armed), Pangu (lame), Muka (dump), Minmin (nasal voice), Jada (mentally retarded), Vaaman (dwarf), Vikrutaksha (dis-shaped eyes) etc. While on the opposite side if the desires of the pregnant lady are fulfilled, she will give birth to a royal, handsome, obedient and healthy child. Further Acharya Sushruta gave a list of desires and their effects on the characters of the child and said that whatsoever untold things are desired by the pregnant wom- 
an, the born child reflects the features, conduct and

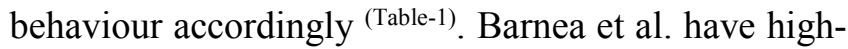
lighted the role of stress factors in the loss of early pregnancy; they have reported their findings of the role of stress factors controlling placental hormonal secretion in human's vitro using static culture.

To keep away from the birth defects and other morbidities, Acharya Charak, Sushruta and Vagbhata has suggested adopting specific month wise dietary regimen during the anti-natal period. This month wise diet schedule is mostly composed of Milk and Ghee processed with Rice, Madhura drugs, Shalparnyadi drugs, honey and butter up to seven months and after seven months Anuvasan and Asthapana basti should be given to counteract the excess Vata and to lubricate the delivery passage. Further this month wise regimen right from first month to nine month of pregnancy helps in softening of placenta, pelvis, waist, and back. These regime regulates the downward movement of Vata, facilitates easy elimination of stool and urine, softening of skin and nails of mother, promotion of strength and complexion of mother and delivery of the offspring with ease of desirable and healthy child endowed with excellent qualities in proper time ${ }^{(\text {Table-2)30 }}$.

\section{CONCLUSION-}

It is evident from the above discussion that intra uterine phase (Garbha) of child is a very important time for rest of his life, and it will decide the fate of the progeny. Acharyas have clearly described the classification of congenital diseases which are at par with the modern system of therapeutics. In brief, if a couple is informed of possibilities that they are at a risk of genetically abnormal child so they should not go for a baby is worthy, and if they wish a healthy child they should take medical advices before conception so a premeditated baby can be planned. Similarly, to avoid congenital birth defects (Supraja) the pregnant woman should follow the dietary regime and opt for Garbha Sanskar methods vigilantly so she will get a rich, handsome and healthy baby.

\section{REFERENCES}

1. Shastri Ambikadutta, Sushrutasamhita-Sutra sthana, Chaukhambha Sanskrit Sansathan, Varanasi, Verse 24/2-6, 2002 edition

2. Shastri Ambikadutta, Sushrutasamhita-Sharirsthana, Chaukhambha Sanskrit Sansathan, Varanasi, Verse 2/35, 2002 edition

3. Birth Defects \& Genetics: Birth Defects" Retrieved on 2007-05-30

4. Dicke JM (1989). "Teratology: principles and practice". Med. Clin. North Am.73 (3): 567-82.

5. Shastri Kashinath, Tripathi Indradev, Tripathi Srikanta, AshtangHridayam-Sharirsthan, Krishnadas Academy, Varanasi, Verse 1/70-71, 1994 edition

6. Vivekanand quotes, Volume-7, www.vivekvani.com

7. Shastri Ambikadutta, Sushrutasamhita-Sharirsthana, Chaukhambha Sanskrit Sansathan, Varanasi, Verse 5/2, 2002 edition

8. Srikanthamurthi K R, Ashtang Sangrah- English translation-Sharirsthana, Chaukhambha Orientalia, Varanasi, Verse-2/3, edition 2009

9. Shastri Kashinath, Chaturvedi Gorakhnath, Charak Samhita- Sharirsthana, Chaukhambha Bharati Academy, Varanasi, Verse- 3/3, $19^{\text {th }}$ edition 1993

10. Shastri Kashinath, Chaturvedi Gorakhnath, Charak Samhita- Sharirsthana, Chaukhambha Bharati Academy, Varanasi, Verse- 4/4, 19 $9^{\text {th }}$ edition 1993

11. Shastri Ambikadutta, Sushrutasamhita-Sharirsthana, Chaukhambha Sanskrit Sansathan, Varanasi, Verse 3/18-37, 2002 edition

12. Shastri Ambikadutta, Sushrutasamhita-Sharirsthana, Chaukhambha Sanskrit Sansathan, Varanasi, Verse 2/53-55, 2002 edition

13. Shastri Kashinath, Chaturvedi Gorakhnath, Charak Samhita- Sharirsthana, Chaukhambha Bharati Academy, Varanasi, Verse- 2/6, $19^{\text {th }}$ edition 1993

14. Shastri Kashinath, Chaturvedi Gorakhnath, Charak Samhita- Sharirsthana, Chaukhambha Bharati Academy, Varanasi, Verse- 3/30, 19 $9^{\text {th }}$ edition 1993

15. Shastri Kashinath, Chaturvedi Gorakhnath, Charak Samhita- Sharirsthana, Chaukhambha Bharati Academy, Varanasi, Verse- 4/30, 19 ${ }^{\text {th }}$ edition 1993

16. Shastri Kashinath, Chaturvedi Gorakhnath, Charak Samhita- Sharirsthana, Chaukhambha Bharati Academy, Varanasi, Verse- 4/31, 19 th $^{\text {edition }} 1993$

17. Shastri Ambikadutta, Sushrutasamhita-Sutra sthana, Chaukhambha Sanskrit Sansathan, Varanasi, Verse 35/13, 2002 edition 
18. Srikanthamurthi K R, AshtangSangrah- English translation-Sharirsthana, Arun Dutta commentary, Chaukhambha Orientalia, Varanasi, Verse-1/5, edition 2009

19. Shastri Kashinath, Chaturvedi Gorakhnath, Charak Samhita- Sharirsthana, Chaukhambha Bharati Academy, Varanasi, Verse- 8/17, 19 th $^{\text {edition }} 1993$

20. Ronan O'Rahilly, Fabiola Müller (2001). Human embryology \& teratology. New York: Wiley-Liss. ISBN 0-471-38225-6

21. James G. Wilson, Environment and Birth Defects (Environmental Science Series). London: Academic Pr. ISBN 0-12-757750-5

22. Bracken MB, Holford TR (1981). "Exposure to prescribed drugs in pregnancy and association with congenital malformations". Obstetrics and gynecology58 (3): 336-44.

23. King CR (1986). "Genetic counseling for teratogen exposure". Obstetrics and gynecology67 (6): 843-6.

24. Linnainmaa K (1983). "Sister chromatid exchanges among workers occupationally exposed to phenoxy acid herbicides 2,4-D and MCPA". Teratog., Carcinog. Mutagen.3 (3): 269-79. doi:10.1002/15206866(1990)3:3<269::AID-

TCM1770030306>3.0.CO;2-F.
25. Vaglenova J, Birru S, Pandiella NM, Breese CR (2004). "An assessment of the long-term developmental and behavioral teratogenicity of prenatal nicotine exposure". Behav. Brain Res.150 (1-2): 159-70. doi:10.1016/j.bbr.2003.07.005.

26. Hunt JR (1996). "Teratogenicity of high vitamin A intake". N. Engl. J. Med.334 (18): 1197. doi:10.1056/NEJM199605023341814.

27. Spanish Julio Nazer H et. REV Med Chil, 2007 Nov (Pub Med)

28. IrisaZile et al.Medicina (Kaunas), 2013 (Pub Med)

29. Shastri Ambikadutta, Sushrutasamhita-Sharirsthana, Chaukhambha Sanskrit Sansathan, Varanasi, Verse 2/31, 2002 edition

30. Shastri Kashinath, Chaturvedi Gorakhnath, Charak Samhita- Sharirsthana, Chaukhambha Bharati Academy, Varanasi, Verse- 8/32, 19 ${ }^{\text {th }}$ edition 1993

31. Sharma RK, Dash Bhagwan, Charak SamhitaSharirsthana, Chaukhambha Sanskrit series office, Varanasi, Verse- 2/29-30, Reprint 2010

32. www.healthline.com

33. www.hitxp.com

34. www.egyankosh.ac.in

Table 1: List of desires expressed by the mother indicative of probable characters of the child

\begin{tabular}{|l|l|l|}
\hline S No & Dauhrida or Desires & Characters of the child \\
\hline 1 & To look at king & Rich, very lucky \\
\hline 2 & To wear very fine silk garments and ornaments & Fond of ornaments and handsome \\
\hline 3 & To live in Ashrama (pious place) & Capable of controlling indriyas and religious \\
\hline 4 & To look at an idol of deity & $\begin{array}{l}\text { Extremely polite and well-mannered like } \text { Parsada } \text { (repre- } \\
\text { sentative of civil society) }\end{array}$ \\
\hline 5 & To look at snake, hyena, fox etc & Violent and ruthless child \\
\hline 6 & To eat meat of iguana (reptiles) & Sleepy, self-constraint and sprinter \\
\hline 7 & To eat cow's meat & Strong, powerful and with good stamina \\
\hline 8 & To eat buffalo's meat & Brave, red eyes and with excessive body hairs \\
\hline 9 & To eat pork meat & Sleepy, brave and bold \\
\hline 10 & To eat deer's meat & Industrious, swift runner and love jungles \\
\hline
\end{tabular}

Table 2: Month wise diet regimen for pregnant lady

\begin{tabular}{|l|l|l|l|}
\hline Month & Charak & Sushruta & Vagbhata \\
\hline 1 & $\begin{array}{l}\text { Pure milk repeatedly according } \\
\text { to her digestive strength and } \\
\text { congenial diet in morning and } \\
\text { evening time. }\end{array}$ & Sweet, cold and liquid diet & $\begin{array}{l}\text { Medicated milk with shalparni } \\
\text { and palasha, sweet, cold and liq- } \\
\text { uid congenial diet for two times. }\end{array}$ \\
\hline 2 & $\begin{array}{l}\text { Take milk medicated with } \\
\text { Madhura drugs }\end{array}$ & Sweet, cold and liquid diet & $\begin{array}{l}\text { Sweetened milk treated with } \\
\text { Kakoli. }\end{array}$ \\
\hline
\end{tabular}




\begin{tabular}{|c|c|c|c|}
\hline 3 & $\begin{array}{l}\text { Take milk with honey and } \\
\text { ghrita. }\end{array}$ & $\begin{array}{l}\text { Sweet, cold and liquid diet and specially } \\
\text { cooked Shastika rice with milk }\end{array}$ & $\begin{array}{l}\text { Krasara (olio prepared with rice } \\
\text { and pulses) }\end{array}$ \\
\hline 4 & $\begin{array}{l}\text { Milk with butter or butter ex- } \\
\text { tracted from milk in the quan- } \\
\text { tity of one aksha should be } \\
\text { given. }\end{array}$ & $\begin{array}{l}\text { Cooked Shastika rice with curd, pleasant } \\
\text { food mixed with butter, milk and meat of } \\
\text { wild animals. }\end{array}$ & Milk with one $a k s h a$ of butter \\
\hline 5 & $\begin{array}{l}\text { Pregnant lady should take Gri- } \\
\text { hta prepared with butter ex- } \\
\text { tracted from milk. }\end{array}$ & $\begin{array}{l}\text { Cooked Shastika rice with milk, pleasant } \\
\text { food mixed with ghrita, milk and meat of } \\
\text { wild animals. }\end{array}$ & $\begin{array}{l}\text { Pregnant lady should take Ghrita } \\
\text { prepared with butter extracted } \\
\text { from milk. }\end{array}$ \\
\hline 6 & $\begin{array}{l}\text { Ghrita prepared from milk } \\
\text { medicated with the drugs of } \\
\text { Madhura group should be giv- } \\
\text { en. }\end{array}$ & $\begin{array}{l}\text { Ghrita or rice gruel medicated with } \\
\text { Gokshura. }\end{array}$ & $\begin{array}{l}\text { Ghrita prepared from milk medi- } \\
\text { cated with the drugs of Madhura } \\
\text { group should be given. }\end{array}$ \\
\hline 7 & $\begin{array}{l}\text { Ghrita prepared from milk } \\
\text { medicated with the drugs of } \\
\text { Madhura group should be giv- } \\
\text { en. }\end{array}$ & $\begin{array}{l}\text { Ghrita prepared with Prathakparnayadi } \\
\text { group of drugs. This helps in proper growth } \\
\text { and development of foetus. }\end{array}$ & $\begin{array}{l}\text { Ghrita prepared from milk medi- } \\
\text { cated with the drugs of Madhura } \\
\text { group should be given. }\end{array}$ \\
\hline 8 & $\begin{array}{l}\text { In eighth month, Acharya } \\
\text { charak says that rice gruel pre- } \\
\text { pared with milk and mixed } \\
\text { with ghrita should be given. }\end{array}$ & $\begin{array}{l}\text { To regulate the Apana Vata the Asthapana } \\
\text { basti should be given with decoction of Ba- } \\
\text { dari mixed with Bala, atibala, stapushpa, } \\
\text { sesame seeds, milk, curd and whey, oil, salt, } \\
\text { madanphala, honey and ghrita followed by } \\
\text { Anuvasana basti of oil medicated with milk } \\
\text { and decoction of Madhura drugs. }\end{array}$ & $\begin{array}{l}\text { To regulate the Apana Vata the } \\
\text { Asthapana basti should be given } \\
\text { with decoction of Badari mixed } \\
\text { with Suskamuli, sour substances, } \\
\text { satpushpa, ghrita, oil and salt } \\
\text { followed by Anuvasana basti of } \\
\text { oil medicated with milk and de- } \\
\text { coction of Madhura drugs. }\end{array}$ \\
\hline 9 & $\begin{array}{l}\text { Use of Anuvasan basti with oil } \\
\text { prepared with the drugs of } \\
\text { Madhura groups or rice gruel } \\
\text { prepared with milk and mixed } \\
\text { with ghrita should be given. } \\
\text { Vaginal tampon of the above } \\
\text { oil should be given to lubricate } \\
\text { the vaginal passage. }\end{array}$ & $\begin{array}{l}\text { Cooked Shastika rice with milk, pleasant } \\
\text { food mixed with ghrita, milk and meat of } \\
\text { wild animals. Asthapana and anuvasana- } \\
\text { basti as described can be given. }\end{array}$ & $\begin{array}{l}\text { Meat soup with cooked rice and } \\
\text { added with ghrita or rice gruel } \\
\text { with good quantity of fat. } \\
\text { Anuvasana basti and oily vaginal } \\
\text { tampon should be given. }\end{array}$ \\
\hline
\end{tabular}

\section{Source of Support: Nil \\ Conflict of Interest: None Declared}

How to cite this URL: Anubha Srivastava et al: Critical Review On Garbhajanya Vikriti (Birth Defects) Described In Ayurveda And Its Modern Aspect. International Ayurvedic Medical Journal \{online\} 2021 \{cited June, 2021\} Available from: http://www.iamj.in/posts/images/upload/1208_1217.pdf 